\title{
THE YOUTH AND PRIMACY AGAINST RELIGIOUS RADICALISM THROUGH THE ORGANIZATION OF MAHASISWA AHLITH THARIQAH AL MU'TABARAH AN NAHDLIYYAH (MATAN) IN INDONESIA
}

\author{
Zulfan Taufik \\ State Institute of Islamic Studies Bukittinggi, Indonesia \\ E-mail: zulfantaufik@iainbukittinggi.ac.id
}

\begin{abstract}
In Indonesia, tariqa has become a choice to counter and fight against the radical groups that target youngsters as prey. An obvious example is the organization of Mahasiswa Ahlith Thariqah Al Mu'tabarah An Nahdliyyah (MATAN). By employing the phenomenological approach, this study considered MATAN as a Muslim youth organization that strongly emphasizes radicalism and positivism among youngsters, especially college students. Also, it maintained that MATAN has strived to synergize intellectuality and spirituality among the students, with claims of loyalty to the preservation of moderate, tolerant, inclusive, and consistent Islam. This preservation concerns shari' $a$ ah, haqiqah, and ma'rifah, and simultaneously maintains awareness as an integral part of Indonesian people living in the country. Therefore, they must obey the country's rules imbued with Pancasila and the 1945 Constitution. These points can inspire every activity of the members of MATAN to actively promote and engage themselves in de-radicalization efforts. Meanwhile, the findings confirmed several studies and surveys conducted in Morocco, Algeria, and Mali, asserting that the tariqa has become a new fondness and is believed to be a savior of youngsters from religious extremism.
\end{abstract}

Keywords: Young people; student; tariqa; Sufism; radicalism; MATAN.

\section{Introduction}

Indonesia, which before the reform era, was known as friendly Islam, had changed its image to an angry Islam. The reformation that formed in the post-New Order era has opened a large space for religious movements to articulate their political and ideological 
aspirations aggressively and demonstratively. It was this change in political contours that has altered the image of Indonesian Islam and the notion of Indonesian Muslims, formerly known as a smiling face, which was tolerant and inclined to be compromised, becoming an "angry face" full of conflicts.

Many indicators showed these conditions. For example, the monitoring reports on the condition of freedom of religion or belief in Indonesia issued by several institutions such as The Wahid Institute, Center for Religious and Cross-Culture Studies (CRCS) of Gadjah Mada University Yogyakarta, and Setara Institute showed that the macro and micro conditions of freedom of religion or belief in Indonesia were poor. Among the grim portraits that hover in the freedom of religion or belief in Indonesia so far include the absence of the government in a variety of violations, the impunity for violators, the omission of violations, and the neglect of victims of violations.

In the last view years, the above conditions are in line with the alarming phenomenon in which the radical movements have penetrated the youth and educational spaces. By activists of radical movements, high school and college students are seen as the most appropriate targets in instilling the ideas they stand for. This is because high school and college students have relatively wide and autonomous social connections. The survey of the Institute for Islamic Studies and Peace (2011), Maarif Institute (2011), and the International NGO Forum on Indonesian Development (2016) showed a trend of increasing radicalization among young people between the ages of 15-30 years. Among the indications are the agreement and justification for a series of acts of violent extremism and terrorism to uphold the Islamic state. In addition, religion, economy, as well as media such as television, online sites, and social media, are no less important in influencing radicalization among young people. ${ }^{2}$

\footnotetext{
${ }^{1}$ Martin van Bruinessen, Contemporary Developments in Indonesian Islam: Explaining the "Conservative Turn" (Singapore: ISEAS, 2013), 21-53; Felix Heiduk, "Between a Rock and a Hard Place: Radical Islam in Post-Suharto Indonesia," International Journal of Conflict and Violence, Vol. 6, No. 1 (2012), 26-40; Zulfan Taufik, "Berebut Kuasa Rumah Tuhan: Ekspansi Ideologi Radikal Melalui Masjid di Kota Bekasi," Islam Realitas: Journal of Islamic and Social Studies, Vol. 4, No. 1 (2018), 21-38.

2 Ahmad Fuad Fanani, "Fenomena Radikalisme di Kalangan Kaum Muda," Maarif: Arus Pemikiran Islam dan Sosial, Vol. 8, No. 1 (2013), 4-13; Bagus Takwin et.al., Studi
} 
Measuring the magnitude of the potential that youth can play in realizing the peacebuilding of the nation, as well as the magnitude of their potential utilized by those who want to spread destructive understanding, coaching and education needs to be a common focus. Equally important, their involvement in growing and caring for the values of peace in the midst of society must be well recognized as a long-term social manifestation.

In contrast to studies that regarded the youth as "victims" of radicalism carried out by adults, as well as victims of uncertain economic and political conditions, this paper focused more on youth as an agency that voiced and carried out the activism in stemming the flow of religious radicalism through tariqa. As in Morocco, the belief that tariqa can be a savior of young people from religious extremism has begun to develop. This is evidenced by a strong tariqa tradition and being a new fondness for young Moroccans. ${ }^{3}$ Likewise, Sufism in the Mali context, Benjamin F. Soares viewed Sufism as part of the expression of "rasta" culture, which is currently also favored by its youth as an alternative to the Islamism movement. ${ }^{4}$

In the Indonesian context since the latter half of the 20th century, it has been noticed how people, both in rural and urban areas, were actively involved in the tariqa and other spiritual assemblies. The current contemporary developments show that Sufism has not disappeared from Muslims around the world, including Indonesia. Sufism is actually showing its new strength in many places, although it has languished under the shadow of other Islamic articulations with stronger public recognition as orthodox. In addition, the tariqa is now considered to be an alternative choice for youth in anticipating the strengthening of radical movements in Indonesia after the New Order.

tentang Toleransi dan Radikalisme di Indonesia: Pembelajaran dari 4 Daerah Tasikmalaya, Jogjakarta, Bojonegoro, dan Kupang (Jakarta: International NGO Forum on Indonesian Development, 2016).

3 Khalid Bekkaoui, Ricardo René Larémont, and Sadik Rddad, "Survey on Moroccan Youth: Perception and Participation in Sufi Orders: Evaluation and Interpretation," The Journal of the Middle East and Africa, Vol. 2, No. 1 (2011), 47-63; Katherine Butler-dines, "Youth Perceptions and Engagement with the Moroccan State' s Promotion of Sufism," Independent Study Project (ISP) Collection Paper 2196 (2015).

${ }^{4}$ Benjamin F. Soares, "Rasta' Sufis and Muslim Youth Culture in Mali," Being Young and Muslim: New Cultural Politics in the Global South and North, 2010. 
This article was based on field studies and library research. I was directly involved as an active participant in the process of regeneration of MATAN through Sulük MATAN 1.2, which took place on December 23-24, 2016 at al-Rabbani Islamic College Jakarta and Sulük. MATAN 2 which was held on February 24-27, 2017 in Cisarua, Bogor. On these two occasions, in addition to receiving various cadre materials and taking their part in the oath deliberation process, I also conducted interviews with administrators and members of MATAN from various campuses in Jakarta and its surrounding areas. I also collected internal organization issues, such as SOPs and Technical Guidelines, and the regeneration Guidelines. For universal data fulfillment, I also collected information from the official website of the organization and the main organization of MATAN, namely Jatman and Nahdlatul Ulama (NU). Overall, for the sake of achieving integrative-interconnected understanding, I used a qualitative paradigm with a phenomenological approach in conducting this research. Furthermore, for the stages and techniques of data analysis, I adopted the analysis procedures pioneered by Miles and Huberman, ${ }^{5}$ namely data reduction, data presentation, and drawing conclusions.

\section{The Narrative of MATAN: The Youth Organization Based on Tariqa}

The presence of MATAN cannot be separated from the role of the adherents of tariqa under the authority of Jam'iyyah Ahlith Thariqah Al Mu'tabarah An Nahdliyyah (JATMAN) or in English Association of Respectable Sufi Orders Affiliated with Nahdlatul Ulama, which was commanded by a Rais 'Am (the leader), Habib Luthfi bin Yahya. Officially, MATAN was initiated on August 2, 2009 in the "Kanzus Sholawat" Building in Pekalongan, Central Java, which was later declared to be one of the mustaqillah lajnah (autonomous bodies) at JATMAN XI Conference at Pondok Pesantren Al-Munawwariyyah, Sudimoro, Malang, East Java, on January 10-14, 2012. ${ }^{6}$

\footnotetext{
5 Mathew B. and Michael Huberman Miles, Analisis Data Kualitatif: Buku Sumber tentang Metode-metode Baru (Jakarta: UI-Press, 1992).

${ }^{6}$ Pengurus Pusat MATAN, SOP dan Juknis Mahasiswa Ablith Thariqoh Al Mu'tabarah An Nabdliyyah (n.p.: 2015), 1-2.
} 
In fact, long before the presence of MATAN officially as described above, in 2000 Habib Lutfi, known as a leader of tariqa who held firm to the ideas of nationalism and the love for the motherland, had a desire to organize young people in the tariqa. However, the idea of the establishment of the organization was able to be embodied in the third period of his leadership in JATMAN, which was a representation of the association of tariqa institutions in Indonesia. Habib Lutfi then called that organization as MATAN. That youth organization based on tariqa was established by several youths and college students in Habib Lutfi's house on August 2, 2009. Habib Lutfi also put great hope in MATAN by saying, "I want some murshid or spiritual guides will be born from MATAN!" "

Although it was named as "college student", MATAN is actually a youth organization that does not limit the understanding of college student to someone who is studying in a college. The term of college students in the context of MATAN is expanded in meaning to students who are currently studying in pesantren and tariqa education. ${ }^{8}$ Thus, MATAN members are not only students who registered at tertiary institutions, but also the practitioners (mubibbin) of a tariqa al-mu'tabarah. For example, the Chairperson of MATAN who has a doctorate and is a lecturer at State Isamic University (UIN) Walisongo Semarang, in this context, is still called as a college student because he is a tariqa practitioner under the guidance of Habib Luthfi bin Yahya.

At the beginning of its development, MATAN grew through a network of Nahdlatul Ulama (NU) clerics in boarding schools that have Perguruan Tinggi Keagamaan Islam (PTKI) or Islamic College. The regeneration process was carried out through the presence of active students who were studying on this campus. The majority of them got the direct guidance from their murshid teachers, who were also the caregivers in the great Islamic boarding schools in Indonesia. In further developments, MATAN also reached public/non-religious colleges. Until now, this organization already has management at central level, regional (provincial level), branch (district/municipal level), and commissariat (university or college level). At the provincial level, a number of management which are quite active include East

\footnotetext{
7 Interview with Hamdani Mu'in on December 24, 2016.

8 MATAN, SOP dan Juknis Mahasiswa Ablith Thariqoh Al Mu'tabarah An Nabdliyyah, Chapter IV, Article 5.
} 
Java, West Java, Central Java, Jakarta, Lampung, Jambi, Riau Islands, East Kalimantan, South Sulawesi, and Yogyakarta. ${ }^{9}$

As an organization established by the tariqa practitioner groups and aims to spread the teachings of tariqa among youth and college students, MATAN bases its struggle values normatively to the Qur'ān, hadith, ijma', and qiyas with the ideology of Ahl al-Sunnah wa alJamā'ah understanding. As for constitutionally, MATAN is obedient to Pancasila, the 1945 Constitution, and PD-PRT Jam'iyyah Ahlith Thariqah Al Mu'tabarah An Nahdliyyah (JATMAN).

As for the great direction of the MATAN movement, it is based on the vision of "the birth of future generations and future leaders who have intellectual acumen, wisdom, and spiritual depth as a basis for building and upholding the glory of the Unitary State of the Republic of Indonesia". The great vision of MATAN which underlines the efforts to build and uphold the glory of the Unitary State of the Republic of Indonesia, is more clearly explained in the following mission: 1) maintaining Pancasila and the 1945 Constitution as the ideology of the Unitary State of the Republic of Indonesia; 2) fostering the love of the motherland and the spirit of nationalism among college students to defend the Unitary State of the Republic of Indonesia; 3) developing the nationality insight among college students; 4) stemming the pace and the flourish of the extremist movements and latenism within the Indonesian college environment; 5) preserving the understanding of Islam a la Ahlussunnah wal Jama'ah based on moderate, tolerant, and inclusive Islam in the college student environment; 6) instilling conscience education among the college students based on spiritual values (tariqa/Sufism) and alakbläq al-mahmüdah; 7) improving the intellectual ability to provide benefits and glory of the Unitary State of the Republic of Indonesia better; and 8) participating in maintaining the heritage of the al-salaf alsălih and their tariqa from an early age.

To realize the great goals of the organization as outlined in the vision and mission above, MATAN bases itself on the foundation of values that are generally contained in Sufism and tariqa. The basic values are al-asäs al-khamsah (Five Basic Principles), which give spirit to the organization and the basis for implementing the vision and mission of the organization. The five basic principles are: 1) Tafaqquh fi al-din means the spirit of the movement which is based on honing

${ }^{9}$ Interview with Ali M. Abdillah on February 27, 2017. 
the abilities and intellectual acumen of MATAN members in the efforts to improve the quality of its human resources in all branches of science integratedly because according to MATAN's belief, all knowledge comes from the All-Knowing, Allah; 2) Iltizām al-täah means the spirit of the college student movement based on the obedience to Allah, Rasulullah, and $\bar{u} l \bar{u}$ al-amr (the leader); 3) Tasfizyat al-quiüb wa tarkiyat al-nafs means the spirit of movement, which is based on the efforts to cleanse the heart and purify oneself, both outwardly and inwardly from all forms of traits and actions that are not good; 4) Hif̌ al-awräd wa al-adhkair means the spirit of the movement based on the efforts to maintain the entire time with the intention to worship Allah Swt. in order to bring benefits, goodness, and reward from Allah. For oneself, others, and the community (nation and state); and 5) Khidmah li al-ummah means the spirit of the movement to provide devotion to humanity as well as the nation and state, because of the form of devotion to Allah entirely.

These five basic principles try to be internalized and contextualized to every member of MATAN in all aspects of life, in order to form generations and future leaders who have Sufistic, intellectual, and nationalist characteristics. Sufistic means having spiritual depth through the practice of tariqa al-mu'tabarah to reach Allah (wusūl ila Allab) so that it can reach the blessing of Allah. Intellectual means having the spirit of learning in improving intellectual ability to provide benefits and the glory of the Unitary State of the Republic of Indonesia. Nationalist means having a spirit of patriotism and nationalism by increasing the love of the motherland to defend the Unitary State of the Republic of Indonesia. ${ }^{10}$

The vivid description of the MATAN narrative above reminds us of the significant role of tariqa in the context of Islamic locality in Indonesia. Tariqa has played a significant role since the process of the arrival of Islam in the archipelago, ${ }^{11}$ the resistance to Dutch

\footnotetext{
10 MATAN, SOP dan Juknis.

11 A. H. Johns, "Sufism as a Category in Indonesian Literature and History," Journal of Southeast Asian History, Vol. 2, No. 1 (March 24, 1961), 10-23; Azyumardi Azra, Jaringan Ulama Timur Tengah dan Kepulauan Nusantara Abad XVII \& XVIII: Akar Pembaruan Islam Indonesia (Jakarta: Kencana, 2013), 14-16.
} 
colonialism, ${ }^{12}$ and in strengthening and filling Indonesian independence with elements of nationalism. ${ }^{13}$

\section{The Promotion of Tariqa and Moderate Islam for the Youth}

In Law No. 40 of 2009 concerning Youth, precisely in Article 1, paragraph 1, stated that "The youth are Indonesian citizens who enter an important period of growth and development aged 16-30 years. Based on the age limit as stated in the law, the number of the in Indonesia in Indonesia reaches 61.68 million people or $24.20 \%$ of the total population of Indonesia, which is 254.9 million people. ${ }^{14}$ The figure of $24.20 \%$ in quantity is sufficiently large. Moreover, in the period 2020 to 2035, Indonesia will experience a rare era called the demographic bonus. In this era, Indonesia is projected to be inhabited by a majority of the productive age population, which reaches $64 \%$ of the total population of 297 million. This percentage will occupy the highest graph in the history of this country. Nevertheless, the important thing that should be noted and concerned is that the youth who occupy a significant proportion in the Indonesian demographic map are those who are currently living in socio-religious situations that lead to the strengthening of conservatism and religious identity. ${ }^{15}$

In Martin van Bruinessen and his friends' report, it was said that the period after Soeharto was a period of "conservative turn". The smiling (friendly) face of Islam has disappeared with the disappearance of the New Order regime. The opinions about the conservative turn in the contemporary period in Indonesia, as stated above, actually cannot be fully generalized. In general, it is indeed

12 Ajid Thohir, Gerakan Politik Kaum Tarekat: Telaah Historis Gerakan Politik Antikolonialisme Tarekat Qadiriyyah-Naqsyabandiyyah di Pulau Jawa (Bandung: Pustaka Hidayah, 2002); Kartono Kartodirjo, Pemberontakan Petani di Banten 1888 (Jakarta: Pustaka Jaya, 1984), 257-282.

13 Martin van Bruinessen, "Saints, Politician, and Sufi Bureucrats: Mysticism and Politics in Indonesia's New Order," in Martin van Bruinessen (ed.), Sufism and the "Modern" in Islam (London: IB Tauris, 2006); Imam Khanafi, "Tarekat Kebangsaan: Kajian Antropologi Sufi terhadap Pemikiran Nasionalisme Habib Luthfie," Jurnal Penelitian, Vol. 10, No. 2 (2018).

${ }^{14}$ Badan Pusat Statistik, Statistik Pemuda Indonesia 2015 (Jakarta: 2015).

15 Muhammad Najib Azca, "Yang Muda, Yang Radikal: Refleksi Sosiologis terhadap Fenomena Radikalisme Kaum Muda Muslim di Indonesia Pasca Orde Baru," Maarif: Arus Pemikiran Islam dan Sosial, Vol. 8, No. 1 (2013), 14-44; Mohammad Iqbal Ahnaf, "Struktur Politik dan Deradikalisasi Pendidikan Agama bagi Anak Muda di Indonesia," Jurnal Pendidikan Islam, Vol. 2, No. 1 (2015), 156. 
difficult to reject the assessment that after the reformation, Islamic identity appeared to be affirmed more firmly in the public sphere-in various sectors such as in economic sphere, political sphere, media, schools, markets, and in the streets through the open dhikr recitation, demonstrations, and in various ways, civilized manner, violent manner, or in commercial. However, as Zainal Abidin Bagir said, the portrayal of this phenomenon as a "conservative turn" was not entirely accurate, because what appeared was the increase of the diversity of the Islam faces in Indonesia. ${ }^{16}$ The reason he proposed was that the atmosphere of political liberalization accompanied democratization, many rivals who had been suppressed by the government suddenly had an equally broad scope of movement. In fact, in certain situations, when the government did not seem to care to keep the boundaries of public discourse, some variants of conservative groups seemed to dominate. This showed that conservative forces existed throughout the New Order era and, even before, and now, in a democratic situation, have more space to appear.

In contrast to Bruinessen's previous views, in Indonesia today, there are other signs of the friendly and universalist face of Islam, represented neatly through Sufism. Even (to a certain extent), religious conservatism has become one of the triggers for a fondness for tariqa in the spiritual search of the community, including the youth. Sufism studies that focus more on piety and noble morals, as well as giving and spreading affection (raḅmat li al-älamin) can be an oasis for the seekers who are bored with labeling and the judgment as unbelievers by the conservatives.

The phenomenon of the outbreak of tariqa movement in the context of modern society, including among the youth, tears down a variety of important arguments before concluding that tariqa which was once attached to the stereotypes of the plebeian and adhered to by parents in rural areas will be crushed by the wheel of massive and fast modernization and globalization. Even social scientists who study Muslim societies throughout the $20^{\text {th }}$ century, using a frame of secularization theory that is "mixed" with modernization theory, simply accept the prediction of the death of tariqa along with the

\footnotetext{
16 Zainal Abidin Bagir, "Pengantar: Membaca Beragam Wajah Islam Indonesia," in Martin van Bruinessen (ed.), Conservative Turn: Islam Indonesia dalam Ancaman Fundamentalisme (Bandung: Mizan, 2014).
} 
acceptance of Muslim countries with Western development models, as well as their educated elite who have abandoned the forms of traditional religious organization. ${ }^{17}$

Many factors are intertwined in the attempt to explain the rise of the tariqa in the contemporary period, which has the core in dissatisfaction with the ongoing conditions. As Wallace said, sociocultural change has caused the people involved in it to feel that the socio-cultural life that surrounds it is no longer satisfying. As a result, we need a new system instead, especially the one that has new features. ${ }^{18}$ Such description can be seen through MATAN members who come with various motivations, which generally revolve around the following two factors: First, as a reaction to the onslaught of modernity along with its following decadence; the alienation from cultural roots, anonymity and meaninglessness, and a crisis of spirituality. Second, the dissatisfaction with the religion formal aspects. In other words, the popularity of Sufism, as seen above, is because it is considered capable of being an antidote to dogmatism and ritualism in religion that neglects the need for mystical expressions and inner experiences which are actually perennial.

In the first factor, the revitalization of Sufism in contemporary period is often understood as a reaction to the negative effects caused by modernity. In other words, modernization is seen as a process that does not always succeed in fulfilling the welfare promises it offers. Materialistic and hedonistic lifestyles to the outbreak of social disorientation and depression are the negative effects and big challenges facing modernization and globalization. The dynamics of modern urban life, which are full of stress, require its citizens to always fill and lighten their hearts and souls. Thus, it is not surprising that Sufism is a destination to find the calm and is considered to be an enlightening solution.

Atmo Prawiro, a doctoral student at UIN Syarif Hidayatullah Jakarta, told about his motivation to become adherents of tariqa and joined MATAN: "I entered tariqa because I wanted to find peace and balance the worldly values that were very massive offered by the urban area. In addition, I can gather with friends who have already

17 A. J. Arberry, Sufism: An Account of the Mystics of Islam (London: George Allen and Unwin, 1950); Clifford Geertz, The Religion of Java (Chicago and London: The University of Chicago Press, 1960).

18 Anthony F. C. Wallace, "Revitalization Movements," American Anthropologist, Vol. 58, No. 2 (1956), 264-281. 
joined tariqa and can spread the values of peace possessed by Sufism". ${ }^{19}$ The same thing was also explicitly stated by Fitri Afina Radityani, a postgraduate student at the Agriculture Institute of Bogor, that the main thing that made her join tariqa was because of personal (psychological) problems. ${ }^{20}$

As for the second factor, the rise of the role of Sufism (including other mystical ideology) is an indication that the developed religious model has become very rational and religious law has become very formalistic and legalistic. That situation then causes silting up and drying up in the appreciation of religion. In other words, religion becomes a series of rules but loses its spirit. An illustration of this second factor can also be seen from the motivation of some students/young people who joined MATAN with the motivation to achieve solemnity in prayer and be able to animate the essence of worship rituals that they routinely conduct. ${ }^{21}$

The attractiveness of MATAN as a youth organization based on tariqa for many college students can be understood if you notice the various efforts that are carried out as stated in the Standard Operating Procedure of MATAN Chapter VI, Articles 11-18 below:

Article 11: In the field of religion, spreading and intensifying the implementation of Islamic teachings according to Ahlussunah wal Jama'ah understanding among the college students. Article 12: In the academic field, actualizing scientific traditions based on Sufism without leaving the element of rational intellect. Article 13: In the field of morals, developing the tradition of Sufism in order to achieve the noble morals among the college students. Article 14: In the field of ukbuwwa ijtimáciyya, strengthening the brotherhood of fellow college students. Article 15: Socializing ethics of Sufism in the midst of campus community. Article 16: In the field of tariqa, striving for the achievement of al-shari' at al-ghawrak wa tariq al-bayda', namely al-shari'ab al-Islämìyah and al-tariqah muttasil sanaduhā ilā Rasūl Allah Șalla Allah 'Alayh wa Sallam. Article 17: In the field of movement, increasing alamr bi al-ma'rüf and al-naby 'an al-munkar, based on al-akbläq almahmüdah and realizing Islam as rạ̣mat li al-'alamin. Article 18: In the

\footnotetext{
19 Interview with Atmo Prawiro (Chairperson of MATAN Branch Ciputat) on January 10, 2017.

${ }^{20}$ Interview with Fitri Afina Radityani (Member of DKI Jakarta MATAN branch) on February 26, 2017.

${ }^{21}$ Interview with Zulfa Ulinnuha on February 26, 2017.
} 
field of watanyah, increasing the love of the motherland, maintaining the establishment of the unitary state of the Republic of Indonesia with the practice and appreciation of Sufism/tariqa ethics. ${ }^{22}$

More technically, the pattern of spreading MATAN is made through recruitment with an activity model called "Ta'aruf MATAN Sufi" or abbreviated as Taman Sufi. This activity contains the beginning introduction about MATAN as a tariqa-based student organization, and in general, about the role of Islamic religion (especially tariqa) in human development efforts, especially in Indonesia, the importance of joining tariqa; and the purpose of joining tariqa. This activity, which is usually carried out at the beginning of a new school year at each commissariat (college level), aims to attract college students to be interested in learning Sufism and tariqa, and participate in regeneration and become members of MATAN.

However, as an organization that is new and an inseparable part of the Nahdlatul Ulama (NU), the pattern and strategy of MATAN in recruiting have not been well structured so far. It occurs because it is still dominated using the NU friendship network. Thus, most of its members are college students affiliated with NU or friends of members who have joined previously. This condition is at least visible in the commissariat in the DKI Jakarta area, such as in UIN Syarif Hidayatullah Jakarta, State University of Jakarta and Agricultural University of Bogor. ${ }^{23}$

As for the regeneration of members of MATAN, the same as organizations in general, implement tiered regeneration using the unique tariqa term, sulük. Suluk is a tradition of tariqa adherents which follows activities under the guidance and direction of the murshid, in order to improve morals, purify charity and clear knowledge. But in contrast to sulük which in the terminology of tariqa is a long and heavy process of spiritual practice, suluk in the context of MATAN is more about education and training in the regeneration of its members. The material presented in sulük includes Aswaja, MATAN, tariqa, Indonesian-ness, and leadership. ${ }^{24}$ Through this regeneration

22 MATAN, SOP dan Juknis Mahasiswa Ablith Thariqoh Al Mu'tabarah An Nabdliyyah, Chapter VI, Articles 11-18.

23 Interview with Atmo Prawiro on January 10, 2017; Interview with Arip Suprasetio on February 26, 2017; Interview Hamzah on December 24, 2017.

24 Interview with Handri Ramadhan on February 26, 2017 
process, MATAN hopes to balance the spiritual and intellectual aspects among college students and increase the inclusiveness of thinking, harmony in acting and spiritual depth in the spirit of youth to build the nation, strengthen the spirit of nationalism, and participate in maintaining the unity and integrity of the Unitary State of the Republic of Indonesia.

\section{Stemming the Religious Radicalism through Tariqa}

"The presence of MATAN is a response to several things, namely: the emergence of an ideology that threatens the Unitary State of the Republic of Indonesia, the rise of the terrorist movement, the proliferation of radical ideologies and movements in universities, the emptiness of inner space among college students, and the development of positivism and pragmatism ways of thinking". ${ }^{25}$

The statement of the General Chairman of MATAN above can also be found clearly in the MATAN organizational profile which says that the background of the existence of MATAN is actually a form of the concern of JATMAN over the symptoms of radicalism and positivism among the college students, which creates an exclusive and pragmatic movement of college student. In this context, the practitioners of the tariqa think that the idea of providing guidance to college students becomes a necessity for the birth of a complete future generation of the nation, namely in the intellectual and spiritual elements. These two elements are prerequisites for the nation's future leaders. For practitioners, college students are an iconic symbol of change for the future of a nation. It is because of the intellectual and critical abilities that can create a new phenomenon and a very extraordinary change. However, this becomes a necessity if the movement of college student is lack of the spiritual aspect which emphasizes the spiritual and moral values. Therefore, it is possible that the movement that arises will bring up the ideas of pragmatic radicalism and get caught up in hedonism for a moment. ${ }^{26}$

The above concern is quite reasonable if we look at the phenomenon in which radical movements have targeted the youth and educational spaces. The high school students and college students, who are in the phase of self-discovery and introduction to the world, are very strategic to be the target in strengthening the

\footnotetext{
${ }^{25}$ Interview with Hamdani Mu'in on December 24, 2016.

26 MATAN, SOP dan Juknis.
} 
religious radicalism movement. Moreover, their position (especially college students), which can be said to have a wide range of relationships and autonomous relations, can be a tool in sowing and spreading the radical ideas.

Indeed, since the past decade, the campuses and the public in Indonesia have been surprised by many cases of terrorism in the name of religion involving university students and alumni, including the religious-based colleges. For example, in 2009, Counterterrorism Special Detachment 88 arrested three students of UIN Syarif Hidayatullah Jakarta on the basis of terrorism and then be sentenced to 4.5 years in prison in September 2010. Next, also in 2010, Counterterrorism Special Detachment 88 arrested two college students of Muhammadiyah Solo University (UMS). In addition, the terrorism which is motivated by the radical and extreme religious understanding, also targets many intellectual graduates of college. In August 2010, Counterterrorism Special Detachment 88 arrested a terrorist suspect named Kurnia who was known as an alumnus of the Chemical Engineering Department of Technology Institute of Bandung (ITB). In 2011, the community was also shocked by the terror of the "Book Bomb" which brought out Peppi Fernando as an important actor. Together with Peppi, 17 people have been arrested on suspicion of being involved in a series of actions. Later, it was found out that 4 of the 17 suspects (including Peppi) had studied at UIN Syarif Hidayatullah Jakarta. ${ }^{27}$

In 2011 the Indonesian Institute of Sciences (LIPI) published a report affirming the phenomenon of radicalism in five well-known campuses in Indonesia: Gadjah Mada University (UGM), University of Indonesia (UI), Agricultural Institute of Bogor (IPB), Diponegoro University (Undip), and Airlangga University (Unair). The investigation of the acts of terrorism that shook Jakarta in 2016 further emphasized how the campuses became a fertile ground for the radical seeding which then grew into the act of terrorism. Bahrun Naim, the mastermind of the action in the capital city, was a young man who began to be active in the radical movement since studying at Sebelas Maret University in Surakarta. The radical seeds that were engraved in his understanding then initiated him to join an international terrorism organization. Consequently, it is clear that the

27 Majalah Tempo, 2-8 Mei 2011. 
campus environment is strongly indicated to contribute to the seeding and to galvanize of new terrorist candidates greatly.

Overall, according to the data of deradicalization target program of the National Agency for Counter-Terrorism (BNPT) in February 2017, 52\% of terrorism prisoners who inhabit the correctional center (Lembaga Pemasyarakatan/LP) were the youth (17-34 years old). It is a fact that needs to be our concern. Various factors can explain the phenomenon of religious radicalism among the youth in Indonesia, which began to appear since the collapse of the New Order regime. Najib Azca summarizes at least three important factors: first, socio-political changes in the period of political transition to democracy that resulted in the escalation of turmoil and uncertainty; second, the change of radical Islamic movement which has some roots since the early period of independence; third, the high rate of unemployment among the Indonesian youth. ${ }^{28}$

Stein Kristiansen also stated the similar opinion that youthbased violence groups in Indonesia began to appear at the same time when the economic crisis, unemployment, and the weakness of state institutions occurred because of the fall of the Soeharto regime in 1998. In these times, the youth suffered due to weak revenues and broken expectations. Consequently, the youth groups were formed and directed with the motivation of the economic income of their members as well as the media forming the identity and existence. Religion, in some cases, is only used as a means of legitimating violence and strengthening group membership. ${ }^{29}$

Related to the phenomenon of radicalism, young age groups, as the agency, are more inclined to be involved with radical social movements than the other age groups. Erik H. Erikson, in his book 'Identity: Youth and Crisis', uses the term identity crisis as a result of the youth's vulnerability entering the transition phase in the age of growth they experience. In this identity crisis situation, a person will tend to experience what is called cognitive opening. ${ }^{30}$ The cognitive opening is an important condition in which a young person opens himself with the possibility of new ideas and views of life, which is

\footnotetext{
28 Stein Kristiansen, "Violent Youth Groups in Indonesia: The Cases of Yogyakarta and Nusa Tenggara Barat", Sojourn: Journal of Social Issues in Southeast Asia, Vol. 18, No. 1 (2016), 110-138.

${ }^{29}$ Ibid.

${ }^{30}$ Erik H. Erikson, Identity: Youth and Crisis (London: Faber and Faber, 1968).
} 
preceded by a crisis where they experience a variety of uncertainties, including self-identity. It is at this stage that youth are very vulnerable to join the radical movement. The examples of cognitive opening occur as a result of associating with the teachings of radical Islamic groups, whether political, salafi, or jih ādi. ${ }^{31}$

Even though many young people experience the process of 'cognitive opening', not many youths really involve in a radical movement. A research done by Wiktorowicz on the involvement of young Muslims in the UK into Al-Muhajirun radical movement based in London revealed that those who were most likely to join the radical movement found that interpretations and institutions represented their expectations and were attracted to them. Thus, the seekers of the significance of religion expanded their perspectives that were out of the main concept. ${ }^{32}$

In this context, the tariqa practitioners are doubtless about the urgency of the idea to introduce and incorporate the teachings of the tariqa among college students through MATAN. In their opinion, the tariqa is a container and a way to find out the matter of lust and its characteristics, form a strong soul based on clarity of thought, and be able to distinguish commendable actions that must be practiced and disgraceful actions that must be abandoned. In addition, the teachings in the tariqa also seek to preserve Islam in the style of Ahlussunnah Wal-Jama'ah which is moderate, tolerant, and inclusive consistently in the field of shari'ah, haqiqah, and ma'rifah in the midst of society in the Unitary Republic of Indonesia based on Pancasila and the 1945 Constitution. $^{33}$

MATAN is a college student organization whose cadres are college students that has appropriate methods and phases in the delivery of the organizational ideology so that it can be well received. At MATAN, the ideology that will be transformed into the cadres is a paradigmatic ideology so that some of the methods used in the battle of mind process are as follows:

Al-Manhaj al-Naqli (textual): a method that holds firmly to the revelation texts literally, especially on the issue of faith-based on the scientific transmission obtained starting from Prophet Muhammad,

\footnotetext{
31 Azca, "Yang Muda, Yang Radikal".

32 Quintan Wiktorowicz, Radical Islam Rising: Muslim Extremism in the West (Boulder, Toronto and Oxford: Rowman and Littlefield Publishers, Inc, 2005), 86.

33 MATAN, SOP dan Juknis.
} 
his friends, al salaf al-salih, to the teachers who teach it directly. This method is taken for granted without having to provide opportunities for the mind except for systematization in the ease of learning, understanding, and practicing the principles of the creed.

Al-Manbaj al-'Aqli (rational): a method that considers the mind as the dominant tool in understanding and translating the revelation texts (naq), so the truth of the texts must also obtain the legitimacy of rational knowledge. The results of rational thinking are then empowered to reinforce textual beliefs.

Al-Manhaj al-I'tidali (moderate): a method of synthesis between rational and textual methods that seek to apply the two methods equally, assuming that sticking to one of the methods above can lead to extremes, fanaticism, and radicalism.

Al-Manhaj al-Jadali (dialectical): the method of dialogue (debate) to defend one's own arguments and break opponents' arguments, both textually and rationally.

Al-Manhaj al-Dhawqi (intuitive): a method used is based on intuition (heart) based on the belief in truth transmitted by Allah directly into the human heart without learning or reasoning. This method follows the method of the Sufis to obtain and discover the truth of knowledge (haqiqah-ma'rifah) directly sourced from Allah. ${ }^{34}$

In other words, the regeneration process through ideological introduction carried out at MATAN is not only based on indoctrination of ideology without the existence of critical thinking. But MATAN balances the textual method with the rational and dialectical method in order to maintain and develop college students' critical reasoning power. In addition, the uniqueness of the regeneration of MATAN is, of course, the use of intuitive methods through the process of spiritual practice. Therefore, the members of MATAN who have not taken their allegiance to a tariqa, will be introduced and taken their allegiance to one of tariqa al-mu'tabarah.

The existence of the regeneration with various methods suitable for the college student is specifically intended to:

As a means of understanding and strengthening the Ahl alSunnah wa al-Jamā'ah creed to members of MATAN, so that it can form the characters that have a strong ideology, have broad scientific insights, are disciplined, militant, and have good morals.

34 Pengurus Pusat MATAN, Pedoman Pengkaderan Mahasiswa Ablith Thariqoh Al Mu'tabarah An Nabdliyyah (n.p.: 2015), 24-26. 
As a forum for the deepening of the Islamic religion as Ahl alSunnah wa al-Jamā'ah, especially in Islamic law.

As a center for education and training in character formation, soul, and moral building for members towards the next generation of the nation which are accountable for the nation and state (nationalism) as an expression of faith and piety to Allah.

As a medium for learning and practicing Sufism in accordance with the teachings of the tariqa exemplified by each member. ${ }^{35}$

In fact, the variety of resistance efforts against religious radicalism carried out by MATAN among college students and youth has also become the same phenomena in several other countries such as Morocco, Algeria, and Mali. In a survey conducted in Morocco, one of the most important findings was that young Moroccans believed that Sufism promotes the values of peace, tolerance, antimodernism, and anti-fanaticism. They were struggling from poverty, lack of employment, social marginalization which made it easy for them to fall into radical Islam. These young people also lived with a choice between drug abuse/criminality and religious fanaticism. The most alarming evidence was the terrorist bombing in Casablanca in 2003. The culprits were the youth from the poorest slums of Casablanca. Due to the terrorist attacks, the Moroccan state adopted Sufism as a component of Moroccan Islam to counter Islamic activism and influence among the youth in particular. This study showed that Sufism could save the youth from extremism. ${ }^{36}$ A survey in Algeria also revealed that the majority of Algerian youth viewed Sufism positively. They believed that it promoted peace, tolerance, and social cohesion. However, at the same time, unlike young people in Morocco, they cannot possibly join the Sufi tariqa because they viewed Sufism as anachronistic and 'not modern'. ${ }^{37}$ Likewise, Sufism in the Mali context, Benjamin F. Soares viewed the Sufism as part of the expression of "rasta" culture which is currently also favored by its youth as an alternative of the Islamism movement.

\footnotetext{
35 MATAN, SOP dan Juknis, 32-33.

36 Butler-dines, "Youth Perceptions", 61-62.

37 Hamidi Khemissi, Ricardo René Larémont, and Taybi Taj Eddine, "Sufism, Salafism and State Policy towards Religion in Algeria: A Survey of Algerian Youth," The Journal of North African Studies, Vol. 17, No. 3 (2012), 547-558.
} 


\section{Concluding Remarks}

Because of their position in the transitional age youth, the youth as an agency on the one hand are often very vulnerable to become victims of religious radicalization by adults who have flared up since the opening of reforms. But on the other hand, their activism can be a pioneer in stemming religious radicalism as clearly seen in MATAN activism.

MATAN_as a tariqa-based college student organizationexists to respond to concerns about the phenomenon of radicalism among the youth and college students. MATAN believes that radicalism occurs because of an imbalance between intellect and spirituality. Therefore, MATAN notices that spirituality in the

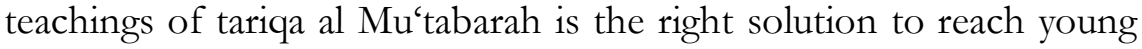
people. By relying on this tariqa, MATAN becomes an organization that is loyal to the preservation of moderate, tolerant, inclusive, and consistent Islam-both in terms of shariah, haqigah, and ma'rifah. These values are aspired to be able to bring the youth to the awareness of living in this country and obeying the rules of this country based on Pancasila and are aware of the efforts of religious radicalism. However, I see that the biggest challenge for MATAN lies in the ability of the strategy to be accepted by young people from various backgrounds. Because until now, the MATAN relation network is still dominated by the NU network—as a "safe" path, considering that tariqa was once the target of marginalization by modernist Muslim groups who consider the tariqa to be a bid'ah and impure. Because of achieving the big vision of preventing radicalism and peace, MATAN must be able to melt away beyond the organizational barriers.

Finally, the findings of this article confirm some studies and surveys conducted in the context of Morocco, Algeria, and Mali, that tariqa becomes a new passion and is believed to be the saviors of youth from religious extremism. The use of tariqa as a weapon of resistance to religious radicalism among the youth, as well as tearing down a variety of important arguments before that tariqa was once attached to the stereotypes of the plebeian and adhered to by parents in rural areas will be crushed by the wheel of massive and fast modernization and globalization. Because it turns out that in the current contemporary context, tariqa still shows its vitality as well as an integral part of the rise of Islam. This is where great hope is placed 
on the shoulders of tariqa as a manifestation of Islamic esotericism that can complement Islamic exoterism which is sometimes rigid and conservative.

\section{Bibliography}

Ahnaf, Mohammad Iqbal. "Struktur Politik dan Deradikalisasi Pendidikan Agama bagi Anak Muda di Indonesia," Jurnal Pendidikan Islam, Vol. 2, No. 1, 2015.

Arberry, A. J. Sufism: An Account of the Mystics of Islam. London: George Allen and Unwin, 1950.

Azca, Muhammad Najib. "Yang Muda, Yang Radikal: Refleksi Sosiologis terhadap Fenomena Radikalisme Kaum Muda Muslim di Indonesia Pasca Orde Baru," Maarif: Arus Pemikiran Islam dan Sosial, Vol. 8, No. 1, 2013.

Azra, Azyumardi. Jaringan Ulama Timur Tengah dan Kepulauan Nusantara Abad XVII \& XVIII: Akar Pembaruan Islam Indonesia. Jakarta: Kencana, 2013.

B. Mathew and Miles, Michael Huberman. Analisis Data Kualitatif: Buku Sumber tentang Metode-metode Baru. Jakarta: UI-Press, 1992.

Bagir, Zainal Abidin. "Pengantar: Membaca Beragam Wajah Islam Indonesia," in Martin van Bruinessen (ed.), Conservative Turn: Islam Indonesia dalam Ancaman Fundamentalisme. Bandung: Mizan, 2014.

Bekkaoui, Khalid., Larémont, Ricardo René., and Rddad, Sadik. "Survey on Moroccan Youth: Perception and Participation in Sufi Orders: Evaluation and Interpretation," The Journal of the Middle East and Africa, Vol. 2, No. 1, 2011.

Bruinessen, Martin van. "Saints, Politician, and Sufi Bureucrats: Mysticism and Politics in Indonesia's New Order," in Martin van Bruinessen (ed.), Sufism and the "Modern" in Islam. London: IB Tauris, 2006.

Bruinessen, Martin van. Contemporary Developments in Indonesian Islam: Explaining the "Conservative Turn". Singapore: ISEAS, 2013.

Butler-dines, Katherine. "Youth Perceptions and Engagement with the Moroccan State's Promotion of Sufism," Independent Study Project (ISP) Collection Paper 2196, 2015.

Erikson, Erik H. Identity: Youth and Crisis. London: Faber and Faber, 1968. 
Fanani, Ahmad Fuad. "Fenomena Radikalisme di Kalangan Kaum Muda," Maarif: Arus Pemikiran Islam dan Sosial, Vol. 8, No. 1, 2013.

Geertz, Clifford. The Religion of Java. Chicago and London: The University of Chicago Press, 1960.

Heiduk, Felix. "Between a Rock and a Hard Place: Radical Islam in Post-Suharto Indonesia," International Journal of Conflict and Violence, Vol. 6, No. 1, 2012.

Interview with Ali M. Abdillah on February 27, 2017.

Interview with Arip Suprasetio on February 26, 2017; Interview Hamzah on December 24, 2017.

Interview with Atmo Prawiro (Chairperson of MATAN Branch Ciputat) on January 10, 2017.

Interview with Atmo Prawiro on January 10, 2017.

Interview with Fitri Afina Radityani (Member of DKI Jakarta MATAN branch) on February 26, 2017.

Interview with Hamdani Mu'in on December 24, 2016.

Interview with Handri Ramadhan on February 26, 2017

Interview with Zulfa Ulinnuha on February 26, 2017.

Johns, A. H. "Sufism as a Category in Indonesian Literature and History," Journal of Southeast Asian History, Vol. 2, No. 1, March 24, 1961.

Kartodirjo, Kartono. Pemberontakan Petani di Banten 1888. Jakarta: Pustaka Jaya, 1984.

Khanafi, Imam. "Tarekat Kebangsaan: Kajian Antropologi Sufi terhadap Pemikiran Nasionalisme Habib Luthfie," Jurnal Penelitian, Vol. 10, No. 2, 2018.

Khemissi, Hamidi., Larémont, Ricardo René., and Eddine, Taybi Taj. "Sufism, Salafism and State Policy towards Religion in Algeria: A Survey of Algerian Youth," The Journal of North African Studies, Vol. 17, No. 3, 2012.

Kristiansen, Stein. "Violent Youth Groups in Indonesia: The Cases of Yogyakarta and Nusa Tenggara Barat", Sojourn: Journal of Social Issues in Southeast Asia, Vol. 18, No. 1, 2016.

Majalah Tempo, 2-8 Mei 2011.

MATAN, Pengurus Pusat. Pedoman Pengkaderan Mahasiswa Ablith Thariqoh Al Mu'tabarah An Nabdliyyah. n.p.: 2015.

-----. SOP dan Juknis Mahasiswa Ablith Thariqoh Al Mu'tabarah An Nabdliyyah. n.p.: 2015. 
Soares, Benjamin F. “'Rasta' Sufis and Muslim Youth Culture in Mali," Being Young and Muslim: New Cultural Politics in the Global South and North, 2010.

Statistik, Badan Pusat. Statistik Pemuda Indonesia 2015. Jakarta: 2015.

Takwin, Bagus et.al. Studi tentang Toleransi dan Radikalisme di Indonesia: Pembelajaran dari 4 Daerah Tasikmalaya, Jogjakarta, Bojonegoro, dan Kupang. Jakarta: International NGO Forum on Indonesian Development, 2016.

Taufik, Zulfan. "Berebut Kuasa Rumah Tuhan: Ekspansi Ideologi Radikal Melalui Masjid di Kota Bekasi," Islam Realitas: Journal of Islamic and Social Studies, Vol. 4, No. 1, 2018.

Thohir, Ajid. Gerakan Politik Kaum Tarekat: Telaah Historis Gerakan Politik Antikolonialisme Tarekat Qadiriyyah-Naqsyabandiyyah Di Pulau Jawa. Bandung: Pustaka Hidayah, 2002.

Wallace, Anthony F. C. "Revitalization Movements," American Anthropologist, Vol. 58, No. 2, 1956.

Wiktorowicz, Quintan. Radical Islam Rising: Muslim Extremism in the West. Boulder, Toronto and Oxford: Rowman and Littlefield Publishers, Inc, 2005. 